\title{
Seroepidemiology Status of Nepalese against Hemolytic Streptococcal Infection in Katmandu
}

\author{
Hiroshi SHIBATA, Katsumi SUMI, Kouichi MIMURA, Akira MATSUOKA, \\ Shiba K RAI* and Mamoru NAKANISHI* \\ Department of Clinical Labotarory, Hyogo College of Medicine \\ *Tribuban University Teaching Hospital \\ (Received: August 14, 1991) \\ (Accepted: October 7, 1991)
}

Key words: hemolytic Streptococcus, Nepal, anti-hemolytic streptococcal antibodies, seroepidemiology status

\begin{abstract}
Immune status of apparently healthy Nepalese against hemolytic streptococci was studied by measuring antibodies to various streptococcal antigens such as streptolysin-O (SO), streptokinase (SK), deoxyribonuclease-B (DN-B) and streptococcal polysaccharide (SP). The normal range of anti-streptolysin$\mathrm{O}$ (ASO), anti-streptokinase (ASK), anti-deoxyribonuclease-B (ADN-B) and anti-Streptococcus polysaccharide (ASP) was 60-480 (T.U.), 40-1024 (titer), 60-1280 (titer) and <2-128 (Unit), respectively. No difference was observed between the two sexes. ASO and ADN-B were measured by the neutralization method. Passive hemagglutination (PHA) was used to measure ASK and ASP. These values were $2-3$ fold higher than those obtained on the Japanese subjects.
\end{abstract}

\section{Introduction}

Hemolytic streptococcal infections particularly by the group-A subclass a common health problem in man. The various clinical manifestations include pharyngitis-tonsillitis, cellulitis, erycepales, puerperal fever, and non-purulent conditions like acute rheumatic fever (ARF) and glomerulonephritis. The streptococcal products like SO, SK, DN-B and SP are immunogenic. Streptococcal antigens are also known to induce auto-immune responses in mammals ${ }^{1)}$ because of molecular mimicry ${ }^{2)}$. Rheumatic fever and post-streptococcal glomerulonephritis are known to be associated to autoimmunity induced by crossreacting streptococcal antigens ${ }^{1)}$. Rheumatic fever and rheumatic heart disease are major health problems in $\mathrm{Nepa}^{3)}$. Detection and estimation of antibodies to various streptococcal antigens are of great value in the clinical field. The normal range of the laboratory test, however, must be established for a particular population. However, no such studies are available from this country to date. We therefore, tried to establish the normal range of hemolytic-streptococcal infections related antibodies, such as ASO, ASK, ADN-B and ASP in the Nepalese adult population.

\section{Materials and Methods}

A total of 111 apparently healthy subjects (students and staff members of T.U., Teaching Hospital, Katmandu, Nepal) were included in his study. Fifty-one were males and 60 females (all 16-30 years old).

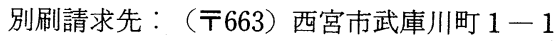

兵庫医科大学病院中央検査部 
Blood samples collected by venipuncture using a disposable syringe were allowed to clot. Sera thus separated were preserved at -70 degree $C$ until the tests were performed. ASO and ADN-B were measured by a neutralization test using kits "SLO" and "Hemoprobe-B" manufactured by Eiken Chemical and Kyorin, Japan, respectively. The PHA test was employed for ASK and ASP with the use of "serodia-ASK" (Fuji Rebio, Japan) and "ASP kit HJ" (Hoechst, Japan). Blood samples were also obtained from Japanese individuals with no hemolytic streptococcal infections visiting Hyogo College of Medicine, Nishinomiya, Japan.

\section{Results}

Table 1 and Fig. 1 show the normal level of anti-streptococcal antibodies (ASO, ASK, ADN-B and ASP)

Table 1 Normal range of ASO, ASK, ADN-B and ASP in Nepalese adult population

\begin{tabular}{|c|c|c|c|c|}
\hline \multicolumn{2}{|c|}{ Antibodies } & $\operatorname{Male}(\mathrm{n}=51)$ & Female $(\mathrm{n}=60)$ & $\operatorname{Total}(n=111)$ \\
\hline ASO & (T.U.) & $60 \sim \quad 480$ & $60 \sim 480$ & $60 \sim \quad 480$ \\
\hline ASK & (Titer) & $40 \sim 10,240$ & $40 \sim 10,240$ & $40 \sim 10,240$ \\
\hline $\mathrm{ADN}-\mathrm{B}$ & (Titer) & $80 \sim 1,280$ & $60 \sim 1,280$ & $60 \sim 1,280$ \\
\hline ASP & (Unit) & $<2 \sim \quad 128$ & $<2 \sim \quad 128$ & $<2 \sim \quad 128$ \\
\hline
\end{tabular}

Fig. 1. Distributions of four types serum antibody titer to hemolytic streptococcal infection in Nepalese and Japanese.

Fig. 1-1

$$
\text { A S O }
$$

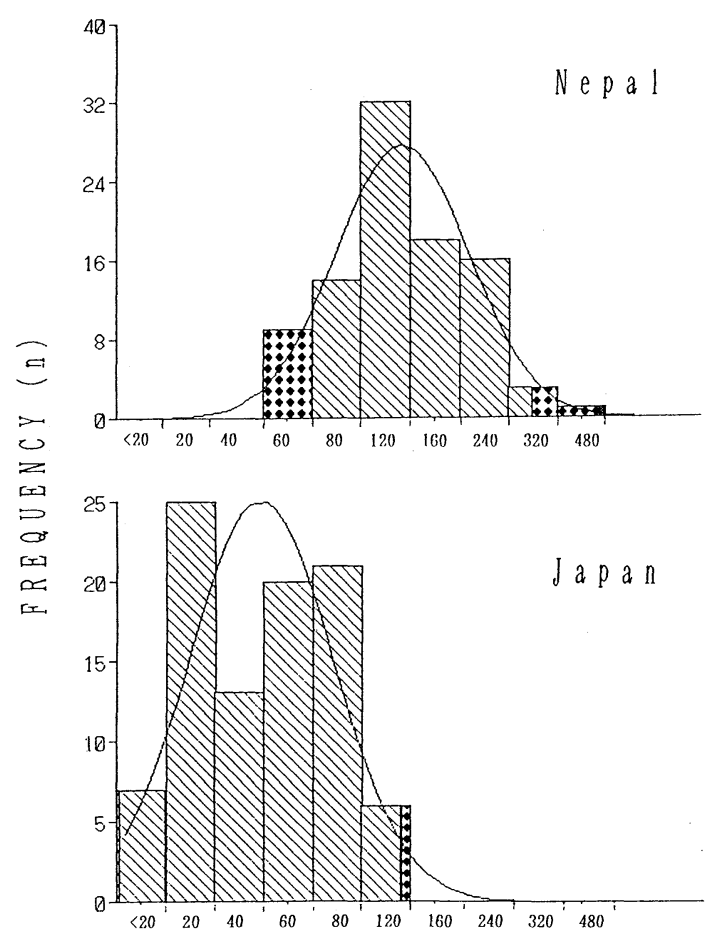

T I TER
Fig. 1-2

$$
\text { A S K }
$$

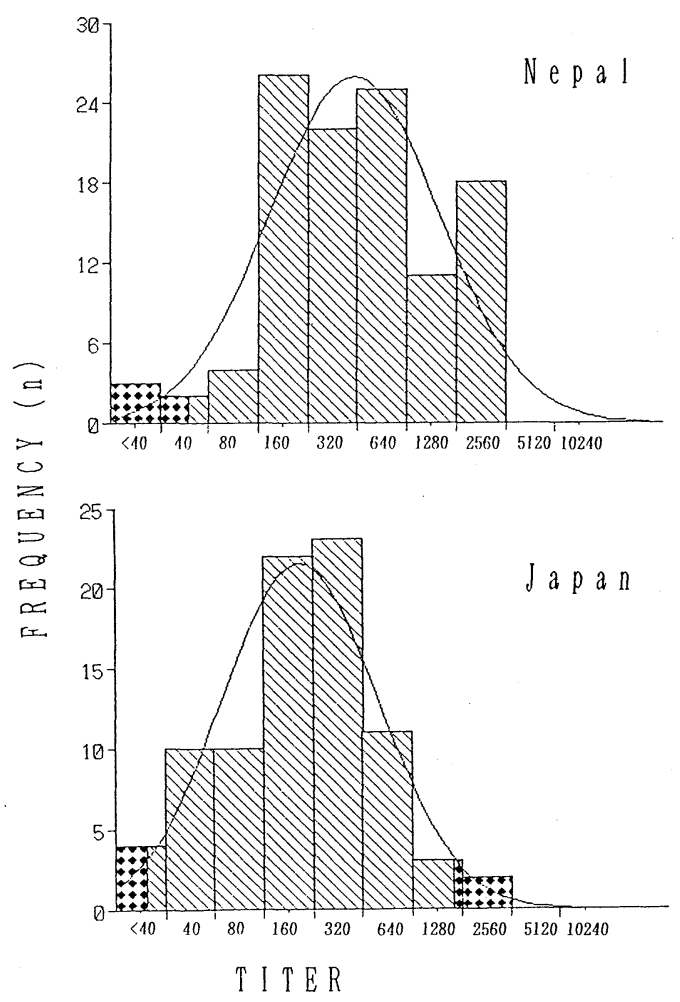


Fig. $1-3$

A $D N-B$

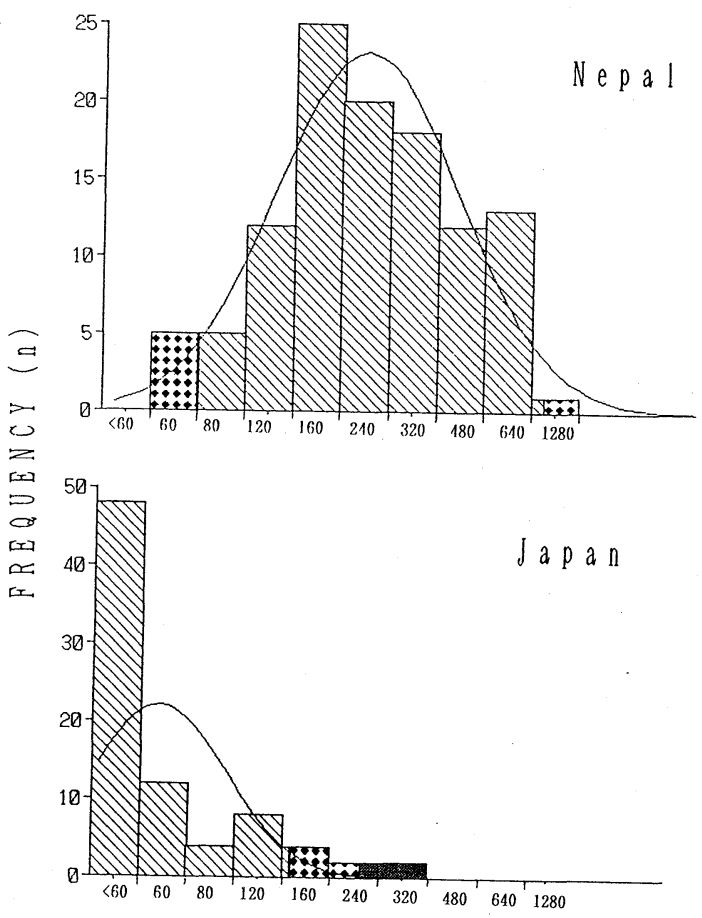

TI T E R
Fig. 1-4

A S P

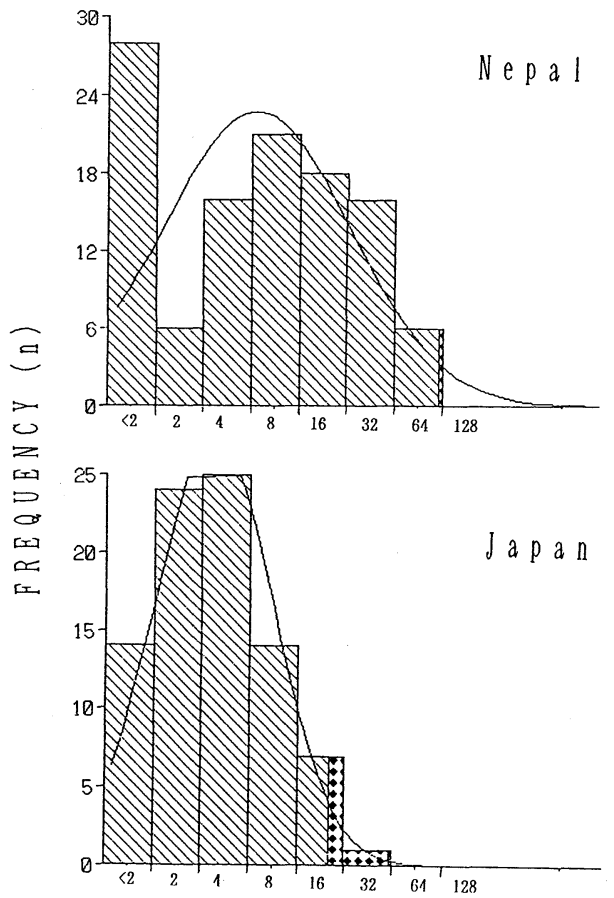

Unit

Table 2 Nomal range of ASO, ASK, ADN-B and ASP in Nepalese and Japanese adult populations

\begin{tabular}{lccc}
\hline \multicolumn{2}{c}{ Antibodies } & $\begin{array}{c}\text { Nepalese } \\
(\mathrm{n}=111)\end{array}$ & $\begin{array}{c}\text { Japanese } \\
(\mathrm{n}=92)\end{array}$ \\
\hline ASO & (T.U.) & $60 \sim 480$ & $<20 \sim 160$ \\
ASK & (Titer) & $40 \sim 10,240$ & $<40 \sim 2,560$ \\
ADN.B & (Titer) & $80 \sim 1,280$ & $<60 \sim 170$ \\
ASP & (Unit) & $<2 \sim 128$ & $<2 \sim 32$ \\
\hline
\end{tabular}

obtained for the apparently healthy Nepalese adults. No difference was observed in the level of these antibodies between the two sexes. The level of these antibodies in Nepalese subjects were $2-3$ fold higher than those in the Japanese subjects (Table 2, Fig. 1).

\section{Discussion}

Hemolytic streptococci consist of group-A and group-B subclasses of streptococci. Group-A streptococci are noted to cause various suppurative and non-suppurative clinical manifestations. Non-suppurative manifestations like ARF and glomerulonephritis are autoimmune diseases resulting from the homology between various streptococcal antigens and mamalation tissues ${ }^{1)}$. It is therefore pertinent to study the immune status of population against the hemolytic streptococci. However, no reports are available from 
this country in regard. This is why we wanted to study the immune status in an apparently healthy Nepalese adult population and thereby to establish the normal range of anti-streptococcal antibodies. In the present study, the normal range of antibodies to SO, SK, DN-B and SF was found to be $60-480$ (T.U.), $40-10240$ (titer), 60-1280 (titer) and $<2-128$ (Unit), respectively (Table 1; Fig. 1). No difference was observed between the two sexes. These antibodies were also measured in Japanese subjects with no hemolytic streptococcal infections. The levels of these antibodies in the Japanese subjects were $2-3$ folds lower than that in the Nepalese subjects (Table 2; Fig. 1). This could be due to the differences in nutritional, social and environmental conditions between the two countries. A low level of antibodies has also been reported from Saudi Arabia ${ }^{4}$. The poverty, over crowding, and other social and environmental factors might have attributed to repeated exposure to the hemolytic streptococci in Nepal thereby leading to an increased level of antibody production. However, a high ASO titer occurs in apparently healthy individuals with no history of streptococcal infection and individuals with disease conditions other than those of streptococcal origin ${ }^{5}$.

The streptococcal polysaccharide is known to have crossimmunity with human heart tissue and a high ASP titer is found in ARF and rheumatic diseases ${ }^{6}$. Rheumatic fever and rheumatic heart disease are reported to be major health problems in Nepal. The exact incidence of post-streptococcal ARF and glomerulonephritis in Nepal however, is not known. Our findings therefore, strongly suggest further elucidation.

The titration of ASO alone is not reliable criteria for the diagnosis of streptococcal infections ${ }^{5}$. ADN-B estimation is reported to be a more sensitive indicator of antecedent streptococcal infections than $\mathrm{ASO}^{7}$. Therefore, serological tests other than ASO are recommended in the diagnosis of a case of streptococcal infection and its sequelae. The present study provides the normal ranges of these serological tests for the Nepalese population. The present study, however, was limited to a young adult population, and therefore the normal range of these serological tests in other age groups remains to be examined.

\section{References}

1) Foude, J., Gibofsky, A., Buskirk, D.R., Khanna, A. \& Zabriskie, J.B.: Cross-reactivity between Streptococcus and Human tissue: A model of molecular mimicry and autoimmunity in CTMI. Vol. 145, p. 5-28, Springer-Verlag, Berlin, Heidelberg, 1989.

2) Daiman, R.T.: Molecular mimicry: antigen sharing by parasites and host and its consequences. AM. Naturalist 98 : 129-149, 1964.

3) Prasad, R., Bhattarai, H. \& Guragain, R.P.S.: Beta-haemolitic streptococci in the throat of asymptomatic Nepalese school children. J. Inst. Med. 12: 1-9, 1990.

4) Hossain, A.: Tests for streptolysin $\mathrm{O}$ antibodies in health and suspected streptococcal infections in Saudi Arabia. J. Trop. Med. Hyg. 90(3): 111-115, 1987.

5) Anyiwo, C.E., Obi, C.L. \& Nnaja, N.A.: Wanning significance of antistreptolysin O (ASO) titers in diagnosing streptococcal infections in Lagos, Nigeria. East Afr. Med. J. 66(10): 636-640, 1989.

6) Fujikawa, S., Ohkumi, M. \& Leu, H.C.: Antibody titer to group A streptococcal polysaccharide in rheumatic fever and rheumatic disease. Jpn. Circ. J. 51(12): 1347-1349, 1987.

7) Koshi, G., Sridharan, G., Thangarelu, C.P. \& Shastry, J.C.: Streptococcal antibodies and complement components in tropical post-streptococcal glomerulonephritis. Trans. Roy. Soc. Trop. Hyg. 77(2): 189-191, 1983. 
カトマンズに拈けるネパール人の溶血性連鎖球菌感染症に

対する血清疫学的調査

兵庫医科大学病院中央臨床検査部
住 勝実 三村 幸一 松岡 瑛
トリブバン教育大学病院臨床病理部

Shiba K Rai 中西守

(平成 3 年 8 月 14 日受付)

(平成 3 年 10 月 7 日受理)

健常ネパール人の溶血性連鎖球菌に対する疫学 状況を，ストレプトリジンO，ストレプトキナー ゼ，デオキシリボクレアーゼ-B，执よびストレプ トポリサッカライド等の種々抗原物質に対する抗 体価測定により調べた。抗ストレプトリジンO (ASO), 抗ストレプトキナーゼ(ASK), 抗デオキ シリボヌクレアーゼ (ADN-B), 执よび抗ストレ
プトポリサッカライド (ASP) 抗体価の健常域は, それぞれ60４80(T.U.)，40１,024倍, 60１,280 倍，および 2 以下～128Unitであった. ASO 価お よび ADN-B価は, 中和反応により測定した。 ASK 価および ASP 価は, 受身赤血球凝集反応に より測定した。これらの測定値は，対照とした日 本人群よりも $2 \sim 3$ 倍高值であった。 